\title{
Design of automatic hand sanitizer based on Arduino Uno Microcontroller
}

\author{
Angga Putra Ramadan ${ }^{1{ }^{*}}$, Linda Marlinda ${ }^{2)}$ \\ ${ }^{12)}$ Universitas Nusa Mandiri, Jakarta, Indonesia \\ 1)*anggaputraramadian25@gmail.com, ${ }^{2}$ linda.ldm@nusamandiri.ac.id
}

Submitted : Sept 30, 2021 | Accepted : Oct 18, 2021 | Published : Nop 11, 2021

\begin{abstract}
The current COVID-19 pandemic is still very worrying and still shows no sign of ending, the development of positive confirmed cases continues to increase every day, plus there are still many people around who wash their hands by touching hand washing tools directly. Therefore, in this study, it is proposed to make an automatic hand sanitizer. An automatic hand sanitizer that is used to help reduce or minimize direct contact in preventing the transmission of COVID-19 that is currently happening. Most hand washing tools, especially hand sanitizers, are used manually by pressing. Arduino is a single board microcontroller or board that is open source or open source, so we can use it or make modifications and it is specially designed to make it easier to create objects or develop electronic devices that can interact with various sensors or controllers, the hardware has an Atmel processor. Based on the Arduino Uno microcontroller with infrared sensor components, relays, and a mini water pump with infrared. by detecting objects, supplying electricity, and turning on the mini water pump. The microcontroller will detect and read when an object is detected, then the relay will conduct electricity to the mini water pump to turn it on.
\end{abstract}

Keywords: Hand Sanitizer, Ardunio Uno, Infrared Sensor, Internet Of Things, Microcontroller

\section{INTRODUCTION}

The current COVID-19 pandemic is still very worrying and still shows no sign of ending, the development of positive confirmed cases every day, the lowest is from January 1, 2021 - April 1, 2021, which is 4,083 cases and the highest is 14,518 cases that occurred throughout Indonesia based on the website COVID-19 Handling Task Force (COVID-19 Task Force, 2021).

Based on information submitted by the World Health Organization (WHO) that one of the transmission methods, namely air, can transmit the Corona virus (Winda \& Prasetyo, 2020). In addition to the mode of transmission of COVID-19, WHO also educates various places where COVID-19 spreads, such as narrow places, crowds, and limited rooms (Sari, 2021).

Based on this information as well as the Indonesian government's instructions to always implement the 5M protocol, namely wearing masks, washing hands, maintaining distance, staying away from crowds, and reducing mobility. One of the government's instructions is to wash hands, either by using running water, added with soap, or directly using hand sanitizer. But seeing the state of the environment around which there is still a lot of hand washing by touching the hand washing tool directly by turning the faucet or holding the hand sanitizer (Syed, 2020), plus the hand washing tool is a public facility that is used by many people, this needs to be watched out for and has the potential for transmission. Corona virus (Jin et al., 2020).

This is the background of the problem for the author to make an automatic hand sanitizer using a microcontroller device that can reduce direct contact with the title "Design of an Automatic Hand Sanitizer Based on the Arduino Uno Microcontroller".

\section{Related research}

\section{LITERATURE REVIEW}

In a study conducted by Faisal \& Arsianti, 2020 about an Automatic Water Faucet System Using Ajdustable Infrared Sensor. In this study, the water faucet was automatically implemented in ablution from the water faucet. If the detected object has a distance of more than $45 \mathrm{~cm}$, the relay will be activated by the Arduino microcontroller so that the solenoid valve can open the faucet valve.

*name of corresponding author 
In a study conducted by Husain, Siregar, \& Permadi, 2020 about Automatically Counting Items Using Infrared Sensors Based on Arduino Uno. In this study, researchers took a case study at PT. Garuda Indonesia, there are domestic cargo goods that come out of the warehouse, the data must be in accordance with the quantities in the field, due to frequent errors in the process of calculating the amount of goods. So the performance of the infrared sensor is needed to facilitate this process, namely by detecting objects and processing them into information in the form of data, namely the number of incoming and outgoing goods.

\section{Internet of Things (IoT)}

Internet of Things (IoT) is an umbrella term that describes any device that is used to collect data from the world around us and then share that data across the Internet where that data can be intelligently processed to provide information and services. This definition can be extended to industrial closed-loop control systems where data is acquired, combined with related data, transmitted to intelligent stations, analyzed, and then acted upon to influence the environment (Cheruvu, Kumar, Smith, \& Wheeler, 2020).

The way IoT works is by using arguments in the improved programming algorithm. The interaction of each structured argument will create a function or work on the hardware. Therefore, the machine does not need assistance from humans because it can be controlled automatically. The most important cause in the program is on the internet network, which serves as a connector between the hardware and the system. The main task of humans is to monitor the actions of machines while working.

\section{Automation}

Automation is the utilization of control frameworks and data innovation to reduce the need for human work in the creation of labor and products (Nabilah et al., 2016). Reducing the role of humans in manual control of electronic equipment is the goal of automation. The use of manual can not be separated from the use of automation, because sometimes automation does not do the work that can only be done with the use of manual. Because of that, the researchers combined the use of automatic and manual controls so that when automatic control could not complete the work, manual control would complete it.

\section{Microcontroller}

Microcontroller is a single chip micro because it is a finished PC framework or most of its components are bundled in a single IC chip (Integrated Circuit). The microcontroller circuit consists of an IC and several supporting components so that it can work properly (Dian, Lalita, \& Zaenudin, 2020).

Microcontroller is basically a computer or PC on a single chip, there is memory, a microprocessor, I/O (Input/Output) lines and others in it. Microcontroller has a lower data processing speed when compared to a PC. The speed of the microprocessor on the microcontroller is 1 to $16 \mathrm{MHz}$, which is lower than the microprocessor owned by the PC, which is up to GHz. In its capacity, PCs can also reach Gbytes, much faster than microcontrollers which have capacities ranging from bytes/Kbytes.

\section{Arduino Uno}

Arduino is an open source or open source electronics platform based on ease of use, both hardware and software. That way, Arduino is a minimal system of hardware and software that prioritizes ease of use. The Arduino core is a microcontroller of various types (Ahyadi, 2018).

Arduino basically consists of two components (i) hardware, the blue board and (ii) software, the program that controls the work of the board. Arduino is a single board microcontroller consisting of an Atmega 328 microcontroller, 110 circuits and RAM. The microcontroller on the Arduino board needs to be programmed via a USB cable. This is the most important advantage of Arduino, that we can directly program the microcontroller on the Arduino board from the computer. Previously we needed a separate programmer to program the microcontroller to do any task. The board can be powered via a USB connection with a computer or from a 7-I2V battery. After the program is uploaded, the board can be disconnected from the computer to make the board work independently (Rai, 2016).

\section{Infrared Sensor (Obstacle)}

Infrared sensors are electronic components that can detect objects when infrared light is blocked by objects. Infrared sensors use infrared LEDs as transmitters and phototransistors as receivers, the infrared module functions as a receiver for infrared rays sent by the transmitter.

When an infrared emitter releases radiation and appears on an object, some of the radiation will return to the infrared receiver. The received sensor output will be determined based on the infrared intensity.

*name of corresponding author 
The operating principle of the infrared sensor circuit is based when infrared light is received through the phototransistor, the phototransistor which will convert the infrared light energy into an electric current which will change as a switch (closed switch) or the actual phototransistor (bass) for a moment.

\section{Relay}

In this unit, the relay interface with the Arduino Uno Board is discussed. Basically relays are electromechanical switches and are controlled by electrical signals, rather than the action of physical switches, Relays are used to switch high voltage loads by low voltage controlling signals. The construction of the relay is such that the SPST relay has a single pole and a throw. single connection, In addition to the two-point relay coil, the relay provides another three pins for connection. The common pin and the NC (Normally Connected) pin provide a connection path when the relay is not energized or activated. When the relay is energized or activated, the path between the common pin and the NO (Normally Open) pin is available for connection (Udayakumar.G.Kulkarni, 2020).

The relay works according to the incoming electricity, when the coil or cable is converted into an iron core from the electric current, the lever will be attracted due to the magnetic force produced in the coil so that the switch is closed. When the magnetic properties of the coil are lost or when it is not electric, the spring will pull the lever to return to the initial position.

\section{Mini Water Pump}

Mini Water Pump or in English, namely Mini Water Pump is a mini-sized water pump that has many functions for the need for a water pump. The smaller than usual Mini Water Pump is remembered for its adjustable water pump class because it has a small size of about $92 \times 46 \times 35 \mathrm{~mm}$, with functional and fairly easy shaping sizes (Putro, Rosmiati, \& Sularsa, 2020).

This Mini Water Pump does not require a large power supply, a small water pump only requires about 12 volts of electricity when working and 6 volts when not in use and also requires about $0.5-0.7$ amperes when the water pump is working and when the water pump is not work only requires about 0.18 amperes.

\section{Mini Breadboard}

Breadboard is a type of circuit board used in prototyping electronic circuits. Sometimes people often refer to it as a prototype board. Breadboard in general is a board needed in electronic circuits that do not require solder to connect the circuit. The following types of breadboard according to the following sizes:

1. Mini Breadboard, the smallest breadboard size with 170 connection points.

2. Medium Breadboard, medium breadboard size with 400 connection points.

3. Large Breadboard, the largest breadboard size with 830 connection points.

\section{Arduino Uno USB Cable}

The USB cable functions in addition to providing electrical power to the Arduino Uno microcontroller as well as a connecting device to the Arduino IDE for programming.

\section{Jumper Cable}

Jumper cable is a component needed as a liaison between two components without the need to use solder to connect the electrical circuit. Jumper cables are usually used to prototype equipment on a breadboard to make it easier to assemble. Several types of jumper cables available in the market include:

1. Male to Male Jumper Cable, is a type of cable that has two ends with protrusions, usually used to connect between connector holes.

2. Male to Female Jumper Cable, is a type of cable that has two different ends, namely the end with a bulge and the end with a hole, usually used to connect components with Arduino.

3. Female to Female Jumper Cable, is a type of cable that has two ends with holes, usually used to connect male terminals.

\section{Power Supply Adapter}

The Power Supply Adapter is needed to provide the electrical power needed by Arduino Uno in addition to using a USB cable and because the USB cable is used for the programming process and the length and width of the cable is not possible with the place, so the author uses an additional Power Supply Adapter. 


\section{METHOD}

Methods and steps of research work starting from the research stages, data collection methods, population, research samples, and data analysis methods.

\section{Research Stages}

In the research stage, the author uses the Research and Development method or abbreviated as R\&D. According to Sugiyono, R\&D is a research method used to produce and test the effectiveness of the product (Koriaty \& Agustani, 2016).

\section{Flowchart Research Stages}

The development model that the author uses as a reference in this study is the Thiagarajan model. The Thiagarajan model is known as the 4-D Model, there are 4 stages in this model, namely the definition stage, the design stage, the development stage, and the dissemination stage (Kurniawan et al., 2017).

The model used by the author in this study is a 4-D model, but the author uses only three stages which will be adapted in this study, namely the define, design, and develop stages. The following is a flow chart and stages:

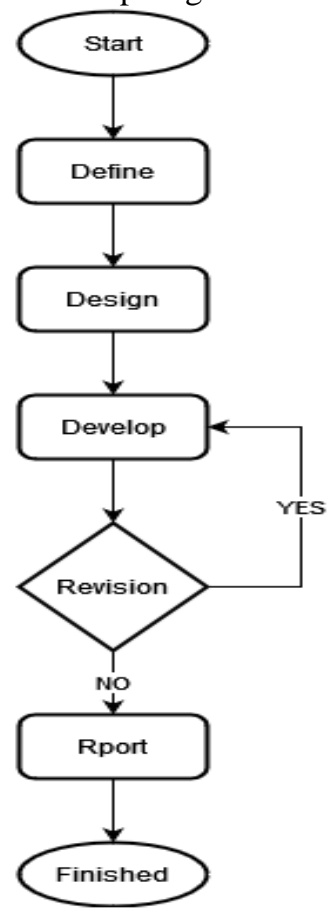

Fig. 1 Flowchart of Research Stages

\section{A. Define}

Looking for a problem that may arise from a phenomenon that has the potential to be researched based on the information and literature that has been obtained. The initial stage is the formulation of the problem which consists of several questions based on the discovery of the problem to be studied, where the question contains the problem to be solved. Second, the preliminary study of this stage is carried out in research which aims to find the information needed by the researcher so that the problem becomes clearer and related to the problem under study. Third, the formulation of the hypothesis is a temporary assumption of the problems that occur and will be proven true after the research is carried out. Fourth, the research sample is part of the population where the characteristics it has are the same as the population. Finally, research plans where each plan must be related to the reasons for research, benefits and research objectives, research objects, research plans and systematic reports.

\section{B. Design}

The design of the tool from analyzing the needs to assembling the tool begins with analyzing the components needed in the design of the tool, the component is needed according to the required function. After that, search for the required components, where these components have their own functions so that the tools designed later are as expected. The next stage is to analyze the design so that the concept can run well in accordance with the required components. The final stage is assembling the components so that they become the desired circuit.

*name of corresponding author 


\section{Develop}

Performing the development stage, namely carrying out several processes, so that there are no errors in the tool, including programming the tool with the help of the Arduino IDE software, so that each component runs according to its functions. there is an error. Finally, analyze the tool. Where the author observes the process flow on each component so that the input that is carried out will run well and produce the expected output.

\section{Report}

Report is a final result of a research in the form of a written document which is the final stage in the research process, which is compiled systematically and writing methods in accordance with research report guidelines.

\section{Data Collection Method, Population and Research Sample}

\section{A. Method of collecting data}

In supporting the truth or accuracy in research in accordance with the needs and research problems, data and information collection is carried out. The steps taken by the author to obtain information are:

1. Primary data, collecting information or data directly to the research site with the observation stage. The author made direct observations by visiting several places that provide a place or hand washing equipment.

2. Secondary data, collecting data or information indirectly through literature such as books, journals, reports and others that aim to obtain information related to research.

The author uses the information that has been collected to be able to find out and start designing the tool, namely how the shape of the tool is in accordance with the place later which is obtained in accordance with primary data and the required components according to secondary data.

\section{B. Population}

All variables related to the topic in research can be in the form of events, objects, people, etc. or the entire number of objects or subjects to be studied is called the population. Population includes the nature, number, and characteristics contained in the subject or object. Even the author can use one object or subject as a population, because one object or subject has various characteristics.

The population used by the author in the design of an automatic hand sanitizer is a hand washing device. Because there are various hand washing tools and their components that affect their use.

\section{Research Sample}

Part of the population is called the sample or some part of the total number of parts is called the population. So that the technique that is suitable for sampling to be carried out by the author is a purposive sampling technique.

Determination of the sample in qualitative research is not based on statistical calculations, information is obtained based on a sample that has been selected with maximum results and is not to be generalized. In determining the research sample, the author uses a purposive sampling technique, namely by taking information sources with certain considerations. Lincoln and Guba define several sample specifications which are purposive sampling, namely:

1. emergent sampling design or temporary.

2. serial selection of sample units or rolling like a snowball.

3. continuous adjustment or focusing of the sample or as needed.

4. selection to the point of redundancy (Wijaya, 2018).

In this case, the author makes certain parts of the hand washing tool, namely the component part, which is a research sample.

\section{Data analysis method}

The method used in data processing to achieve the goal is data analysis method, in conducting research on the design of automatic hand sanitizers tend to use analysis and are descriptive. Meaning and process are further demonstrated in the study. The theoretical basis is used as a reference for the author so that the focus in research can be in accordance with the truth contained in the field, the method that will be used by the author to conduct the research is a qualitative method. The following is an overview of the data analysis process in qualitative research by Miles and Huberman (Rijali, 2019). 


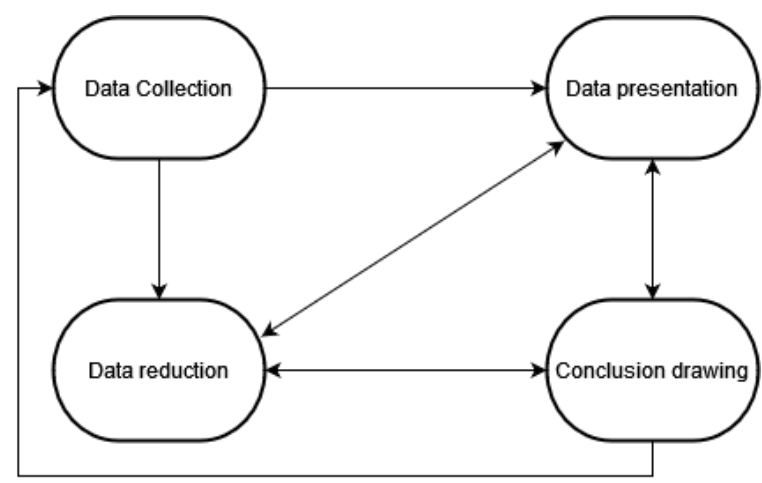

Fig. 2 Process of Qualitative Research Data Analysis

\section{A. Data collection}

The author collects data to support the truth or accuracy in research in accordance with the needs and research problems.

\section{B. Data reduction}

Data reduction is a way to select, focus on deciphering, abstracting and changing rough information that emerges from notes written in the field (Rijali, 2019).

\section{Data Presentation}

Data presentation is the compilation of a collection of information that provides the possibility of taking action and drawing conclusions. Narrative texts or field notes, graphs, matrices, networks, and charts are forms of presenting qualitative data (Rijali, 2019).

In presenting the data, the writer arranges the information that has been obtained from observation, namely based on the type and placement as follows.

Table 1

Types and Placement of Hand Wash Tools

\begin{tabular}{|l|l|}
\hline \multicolumn{1}{|c|}{ Type } & \multicolumn{1}{|c|}{ Placement } \\
\hline Sink Faucet & Bottom \\
\hline Gallon Faucet & Bottom \\
\hline Hand Sanitizer Spray & Bottom, Top \\
\hline Hand Sanitizer Gel & Bottom, Top \\
\hline
\end{tabular}

The purpose of the Bottom or Top placement is the location where the tool is placed with the help of the tool or not. Because the placement of the tool is very influential on the final result of the design of the tool.

\section{Conclusion Drawing}

Conclusions are drawn after the authors collect and describe the data by reducing it continuously so as to produce conclusions and be supported by valid data according to research needs.

\section{RESULT}

The author will discuss from preparation, design, testing to analysis. In the discussion, we will find out how an Arduino microcontroller-based automatic hand sanitizer is made, process flow, programming, and others.

\section{Tools and materials}

In supporting the design of this automatic hand sanitizer, there are the tools needed, along with the price list for the tools and materials that the author uses in this design.

Table 2

Price List of Tools and Materials

*name of corresponding author 


\begin{tabular}{|c|c|c|c|c|}
\hline No & Tool's name & Amount & Unit price & Total price \\
\hline 1 & Arduino Uno R3 + USB & 1 & Rp59.700,00 & Rp59.700,00 \\
\hline 2 & Infrared Sensor & 1 & Rp5.150,00 & Rp5.150,00 \\
\hline 3 & Relay & 1 & Rp5.600,00 & Rp5.600,00 \\
\hline 4 & Mini Water Pump & 1 & Rp16.500,00 & Rp16.500,00 \\
\hline 5 & Mini Breadboard & 1 & Rp3.395,00 & Rp3.395,00 \\
\hline 6 & Jumper Cable & 19 & Rp300,00 & Rp5.700,00 \\
\hline 7 & Power Supply Adapter & 1 & Rp17.700,00 & Rp17.700,00 \\
\hline 8 & Acrylic 20x10 (cm) & 6 & Rp5.000,00 & Rp30.000,00 \\
\hline 9 & Acrylic Hinge & 2 & Rp3.500,00 & Rp7.000,00 \\
\hline \multicolumn{4}{|r|}{ Total } & Rp150.745,00 \\
\hline
\end{tabular}

\section{Flowchart}

The following is the process flow from the detected object until the sanitizer liquid comes out.

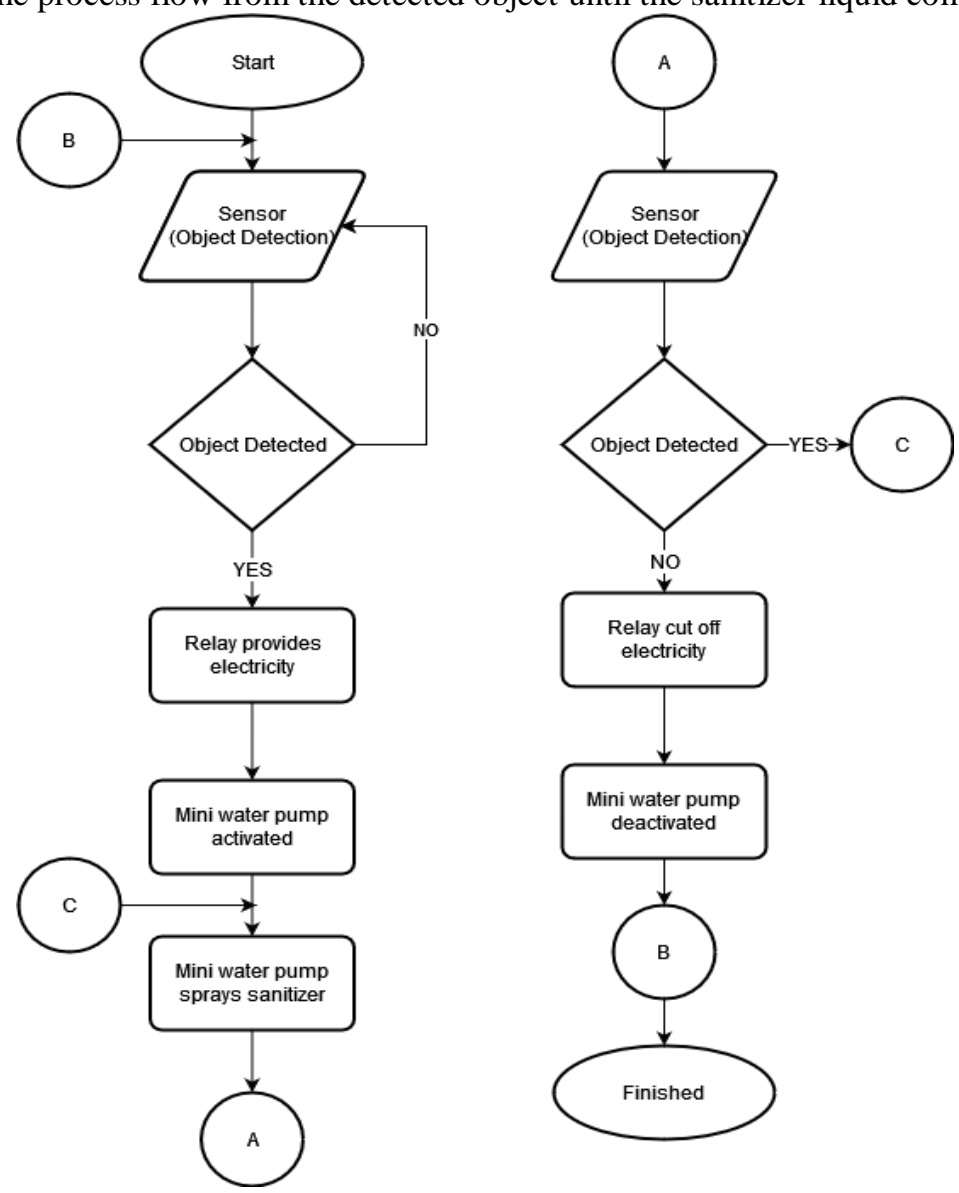

Fig. 3 Flowchart

*name of corresponding author 


\section{Circuits and Tests}

The author has designed a series and tested the hand sanitizer as follows.

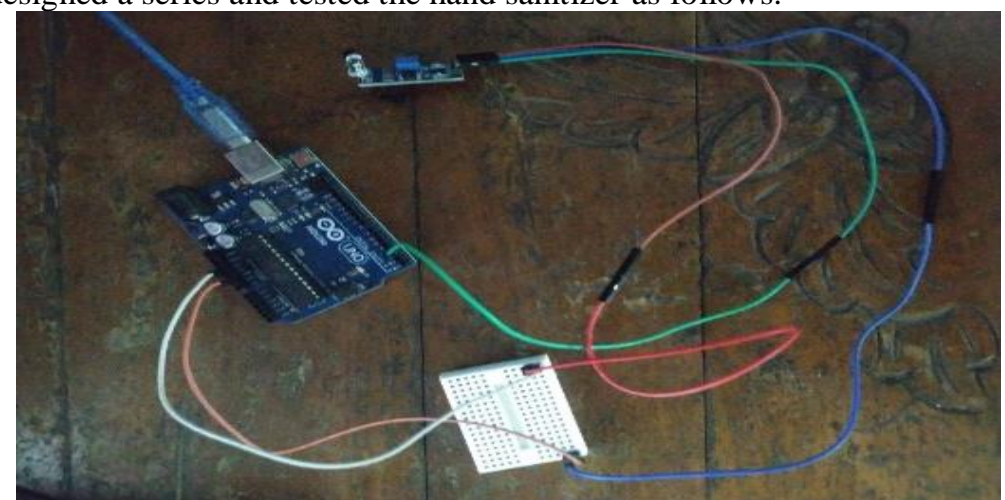

Fig. 4 Result of Arduino Uno Circuit and Infrared Sensor (Obstacle)

After the author has assembled the Arduino Uno, Infrared Sensor, and Breadboard, the next step is testing the sensor to ensure whether the sensor is running and functioning properly. The test is carried out using the Arduino IDE software to program the script into the Arduino Uno so that it can process the Infrared Sensor.

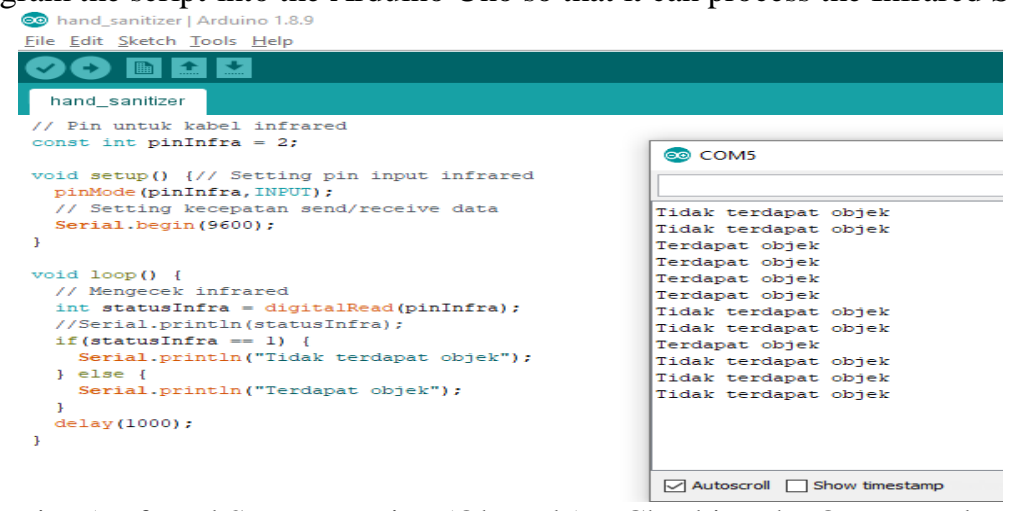

Fig. 5 Infrared Sensor Testing (Obstacle) - Checking the Output Value

After the author gets the output / output value from the sensor, then the author checks using the if-else branch to ensure whether the output value is in accordance with the experiments that have been carried out.

The results obtained by the author are that if the value in statusInfra is equal to 1 then the output that comes out is There is no object, on the contrary if the value of statusInfra is equal to 0 then the output that comes out is There is an object. From the branching carried out and the results obtained, it can be ascertained that the output value is in accordance with the experiment.

\section{Relay Circuit and Mini Water Pump}

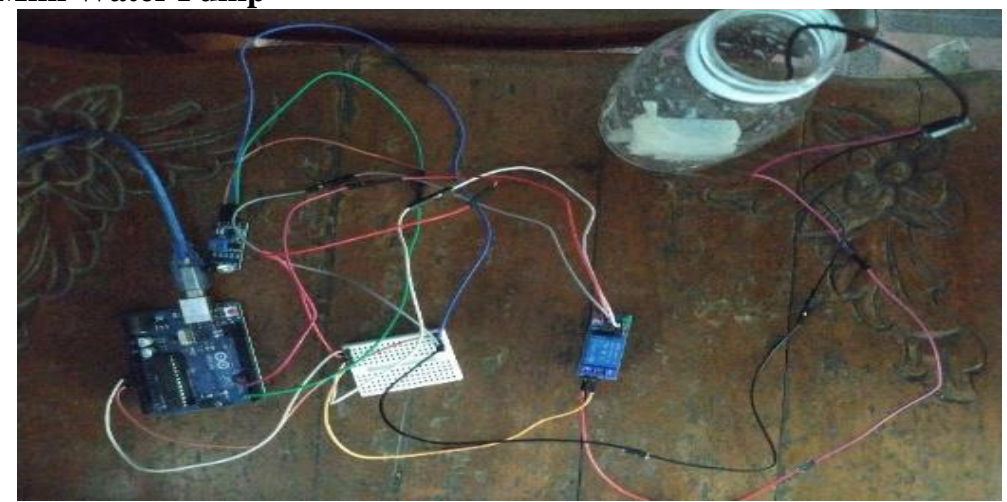

Fig. 6 Results of the Relay and Mini Water Pump Circuits

*name of corresponding author 
After the Arduino Uno circuit and Infrared Sensor (Obstacle) are complete, then connect to the Relay and Mini Water Pump. Previously the author did not use the Relay because it was in the component testing phase, and when the author tried the Mini Water Pump with Infrared Sensor the pump could not be controlled and continued to turn on, because the author wanted when there was an object on the sensor the pump would be active, this is where the Relay function works, namely it can control the flow of electricity automatically according to the logic given, so that the Mini Water Pump can be activated and deactivated.

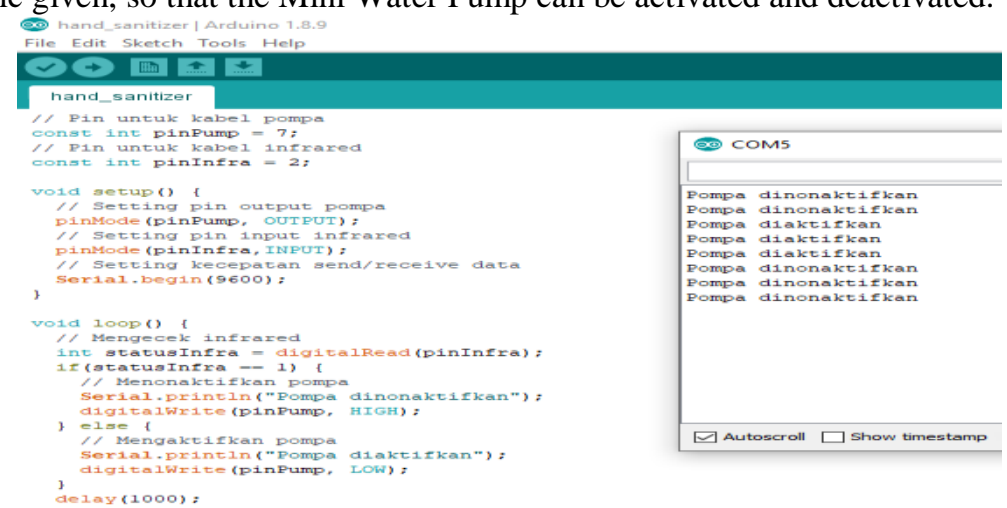

Fig. 7 Mini Water Pump Test

In testing the Mini Water Pump, the author uses pin 7 for the pump component with an integer variable declared pinPump, then uses the value of the Infra status, namely the Infrared Sensor, if the value is 1, it means there is no object, then the output that comes out is Pump disabled plus a function to disable the pump, namely digitalWrite ( pinPump, HIGH), otherwise if the sensor contains an object, the output that comes out is Pump activated plus a function to activate the pump, namely digitalWrite(pinPump, LOW).

\section{The final result}

At this stage, the final assembly of the previous series of components with a place for the hand sanitizer container will be carried out, then an automatic hand sanitizer will be checked for output or output on the serial monitor whether the action received is in accordance with the output displayed.

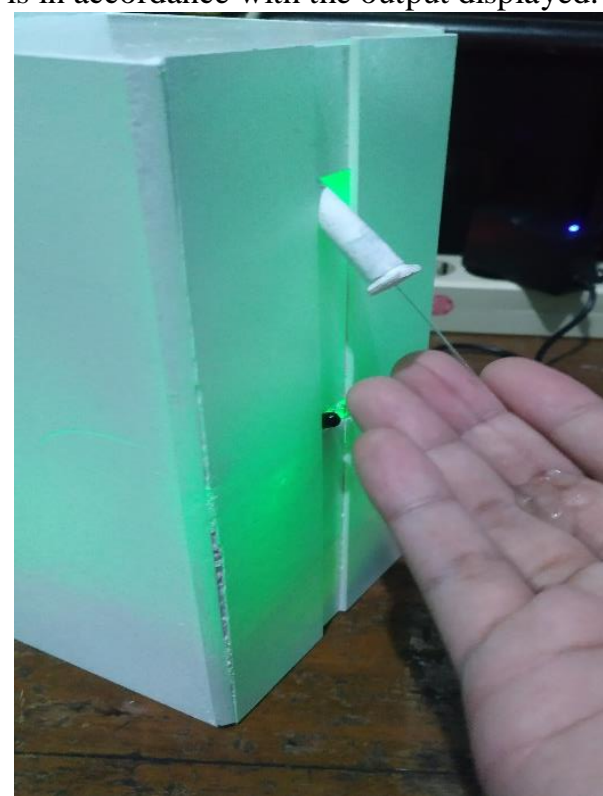

Fig. 8 After the Infrared Sensor Detects the Object

The author made a place made of acrylic for the component series container and bottles (to be filled with sanitizer liquid) with a width and height according to the size of the component and bottle series, the component series is located under the bottle with an acrylic partition that can be removed and there are two holes located in the middle and located above. The hole on the top is for the sanitizer liquid outlet and the second hole is for the infrared sensor.

*name of corresponding author 
In the picture above there are conditions before and after the sensor detects an object and there is also an adapter to provide electrical power. In the hole above there is a hose for the sanitizer liquid to come out and a hole in the middle for the infrared sensor, when there is an object in the middle that blocks the sensor, the sanitizer liquid will come out from the hose in the hole above.

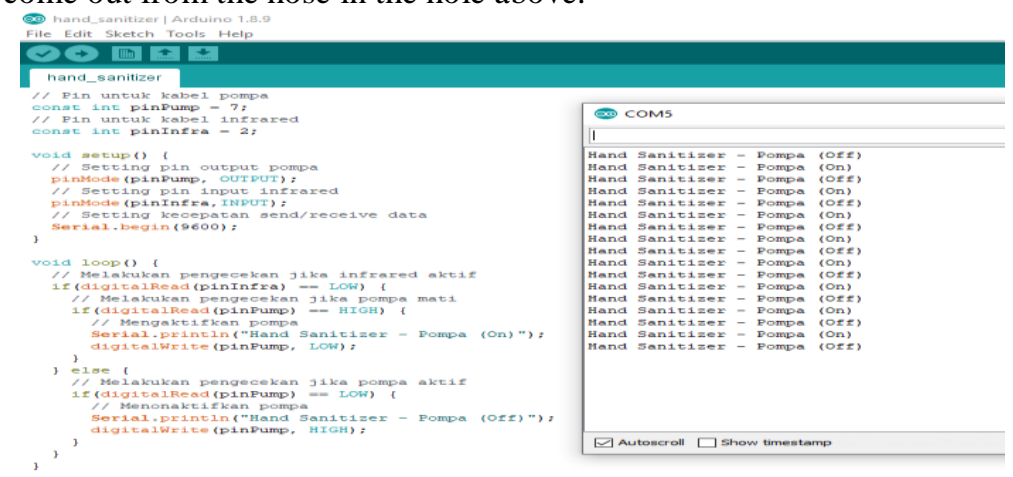

Fig. 9 Output Hand Santizer

In the picture above it can be seen that when the sensor does not detect an object, the output that comes out is Hand Sanitizer - Pump (Off) and the pump is not turned on, on the other hand if the sensor detects an object then the output that comes out is Hand Sanitizer - Pump (On) and the pump is in a state of lights up like the second image in Fig. 10, the green color looks brighter because the indicator light on the infrared sensor lights up when it detects an object.

\section{DISCUSSIONS}

This automatic hand sanitizer design uses Arduino Uno as a microcontroller due to the ease of testing tools and components, there are also many modules that can be used for various needs. The place for hand sanitizer is made according to the components and their placement (with or without the help of tools), such as on a wall or table.

The price of tools and materials for this design is more expensive than tools on the market, but in terms of size, customization and testing of this design, it is relatively cheap compared to tools on the market.

\section{CONCLUSION}

The results of this design study indicate that the automatic hand sanitizer can work well and can spray the sanitizer automatically when the infrared obstacle sensor detects an object. After the object is detected, the relay will supply electricity to the mini water pump, so that the mini water pump is active and sprays the liquid out. When there is no object on the sensor, the relay will cut off electricity and the mini pump will be deactivated.

This tool can be placed on a table or hung on the wall with the help of nails, but this tool requires electricity to function, such as a socket that is close to this tool. Therefore, further research can use the battery connector as a substitute for an adapter for a power source that can minimize areas far from electricity coverage.

\section{REFERENCES}

Ahyadi, Z. (2018). Belajar Antarmuka Arduino Secara Cepat Dari Contoh - Zaiyan Ahyadi - Google Buku. Deepublish. Retrieved from https://books.google.co.id/books?id=M46IDwAAQBAJ

Cheruvu, S., Kumar, A., Smith, N., \& Wheeler, D. M. (2020). Demystifying Internet of Things Security. In Sunil Cheruvu, A. Kumar, N. Smith, \& D. M. Wheeler (Eds.), Demystifying Internet of Things Security. Apress. https://doi.org/10.1007/978-1-4842-2896-8

Dian, A., Lalita, D. F., \& Zaenudin, N. M. (2020). Perancangan Dan Pembuatan Alat Inkubator Berbasis Mikrokontroler. 9(1), 52-62.

Faisal, M., \& Arsianti, R. W. (2020). Sistem Kran Air Otomatis Menggunakan Sensor Infrared Ajdustable. Jurnal: Elektrika Borneo (JEB), 6(1), 20-24.

Husain, A., Siregar, D. C., \& Permadi, S. H. (2020). Alat Penghitung Barang Secara Otomatis Menggunakan Sensor Infrared Berbasis Arduino Uno. Journal CERITA, 6(2), 198-205. https://doi.org/10.33050/cerita.v6i2.1160

Jin, X., Leng, Y., Gong, E., Xiong, S., Yao, Y., Vedanthan, R., Yan, L. L. (2020). Neighborhood-level public facilities and COVID-19 transmission: A nationwide geospatial study in China. MedRxiv. https://doi.org/10.1101/2020.08.25.20181362

Koriaty, S., \& Agustani, M. D. (2016). Pengembangan Model Pembelajaran Game Edukasi Untuk Meningkatkan *name of corresponding author 
Minat Siswa Kelas X TKL SMK Negeri 7 Pontianak. Jurnal Edukasi, 14(2), 277-288.

Kurniawan, D., Dewi, S. V., Pendidikan, J., Fakultas, M., Dan, K., Pendidikan, I., \& Siliwangi, U. (2017). Pengembangan Perangkat Pembelajaran Dengan Media Screencast- O-Matic Mata Kuliah Kalkulus 2 Menggunakan Model 4-D Thiagarajan. Jurnal Siliwangi, 3(1).

Nabilah, N., Islam, H. I., Saputra, D. H., Pradipta, G. M., Said, S., Kurniawan, A., \& Syafutra, H. (2016). Pembuatan Prototipe Lampu Otomatis Untuk Penghematan Energi Berbasis Arduino Uno Di Departemen Fisika Fmipa Ipb. V, SNF2016-CIP-73-SNF2016-CIP-78. https://doi.org/10.21009/0305020115

Putro, F. C., Rosmiati, M., \& Sularsa, A. (2020). Dispenser Pintar Menggunakan Sensor Jarak Berbasis Arduino (Distis). 6(1), 267-272.

Rai, N. (2016). Arduino Projects for Engineers (N. Rai, Ed.). BPB Publications. Retrieved from https://books.google.com.mx/books?id=C41jDwAAQBAJ

Rijali, A. (2019). Analisis Data Kualitatif. Alhadharah: Jurnal Ilmu Dakwah, 17(33), 81. https://doi.org/10.18592/alhadharah.v17i33.2374

Sari, D. P. (2021). Implementasi Algoritma K-Means Dalam Menentukan Tingkat Penyebaran Pandemi Covid-19 Di Sumatera Barat. CBIS Journal, 01, 50-56.

Satgas COVID-19. (2021). Peta Sebaran. Retrieved April 16, 2021, from Https://Covid19.Go.Id/Peta-Sebaran website: https://covid19.go.id/peta-sebaran

Syed, A. (2020). Coronavirus : A Mini-Review. 6, 8-10.

Udayakumar.G.Kulkarni. (2020). Arduino: A Beginner's Guide 2nd Edition (Udayakumar.G.Kulkarni, Ed.). Udayakumar.G.Kulkarni. Retrieved

from https://www.google.co.id/books/edition/Arduino_A_Beginner_s_Guide_2nd_Edition/-_v5DwAAQBAJ

Wijaya, H. (2018). Analisis Data Kualitatif Ilmu Pendidikan Teologi. In Hengki Wijaya (Ed.), Populasi dan Sampel. Sekolah Tinggi Theologia Jaffray. Retrieved from https://www.google.co.id/books/edition/Analisis_Data_Kualitatif_Ilmu_Pendidikan/5AFiDwAAQBAJ

Winda, D., \& Prasetyo, H. (2020). Perlindungan Hukum Bagi Konsumen Pengguna Alat Pelindung Diri Berdasarkan Undang Undang Perlindungan Konsumen ( Studi Kasus PT Brilian Cipta Nusantara) Legal Protection Of Consumers Using Self-Protective Equipment Based On. (1), 978-979. 